\title{
Effects of Body Temperature Lowering on Visual Evoked Potentials in Patients with Multiple Sclerosis
}

\author{
Multipl Sklerozlu Hastalarda Vücut Sıcaklığındaki Düşüşün Görsel Uyarılmış \\ Potansiyeller İncelemelerine Etkisi
}

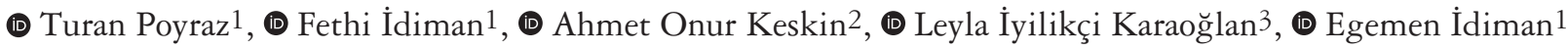 \\ 1Dokuz Eylul University Faculty of Medicine, Department of Neurology, Izmir, Turkey \\ Baskent University Dr. Turgut Noyan Application and Research Center, Department of Neurology, Adana, Turkey \\ 3Dokuz Eylul University Faculty of Medicine, Department of Anesthesiology and Reanimation, Izmir,Turkey
}

\begin{abstract}
Objective: Aggravation of neurologic symptoms in patients with multiple sclerosis (MS) due to heating is well known. This phenomenon, known as Uhthoff phenomenon (UP), is explained by transient conduction block in demyelinated nerve fibers and transected axons. The threshold of conduction block dependent on temperature is probably proportional to the degree of demyelination or axonal injury. On the other hand, about half of all patients reported improvement in a cold bath (anti-UP effect). This study aimed to assess the effects of body cooling on clinical parameters [neuro-opthalmologic examination and contrast sensitivity in visual acuity/Sloan letter test, and the Expanded Disability Status Scale (EDSS)] and electrophysiologic measurements [visual evoked potentials (VEP)] in patients with MS previously clinically affected by optic neuritis.

Materials and Methods: Twenty patients who described a UP or anti-UP effect with definite MS according to the McDonald and Poser criteria were enrolled in the study. Before the cooling process, all patients with a history of optic neuritis (at least once) were examined clinically, neurologically and neuro-ophthalmologically, and electrophysiologically. Body cooling was achieved using a "Medivance Arctic Sun Temperature Management System" and the body temperature was decreased by about $1{ }^{\circ} \mathrm{C}$. After that, all patients were re-evaluated clinically and electrophysiologically.

Results: After the cooling process, P100 latency significantly shortened at the $1^{\text {st }}, 6^{\text {th }}$ and $24^{\text {th }}$ hours $(\mathrm{p}<0.001, \mathrm{p}<0.001, \mathrm{p}<0.001)$ and EDSS scores improved significantly $(\mathrm{p}<0.001)$. Visual acuity, including contrast sensitivity and color vision, significantly improved in both affected and unaffected eyes $(\mathrm{p}<0.001)$.

Conclusion: These results suggest that heat caused a conduction block in demyelinated or transected axons in the visual pathways. Our results also demonstrate that the cooling process had beneficial effects on clinical disability scores (EDSS) and the visual system based on clinical and electrophysiologic (VEP) evaluations. These findings suggest that the cooling process may be used for symptomatic therapy and increasing life quality of patients with MS.
\end{abstract}

Keywords: Multiple sclerosis, visual evoked potentials, cooling effect, Uhthoff s phenomenon

$\ddot{O} \mathbf{z}$

Amaç: Multipl sklerozlu (MS) hastalarda sıcaklık artışı ile nörolojik semptomlarda kötüleşme iyi bilinen bir özelliktir. Uhthoff fenomeni (UF) olarak bilinen bu fenomen, demiyelinize sinir liflerinde ve aksonlarda oluşan geçici iletim bloğu ile açıklanmaktadır. Sıcaklığa bağlı iletim bloğu eşiği muhtemelen demiyelinizasyon veya aksonal yaralanma derecesi ile orantılıdır. Öte yandan, hastaların yaklaşık yarısı soğuk bir banyo ile iyileşme bildirmiştir (anti-UF etkisi). Bu çalışma, optik nevrit atağı geçirmiş olan multipl sklerozlu hastalarda vücut sıcaklığındaki azalmanın klinik parametreler [nöro-oftalmolojik muayene ve kontrast duyarlılık/ Sloan mektup testi ve Genişletilmiş Özürlülük Durum Ölçeği (EDSS)] ve elektrofizyolojik ölçümler [görsel uyarılmış potansiyeller (VEP)] üzerindeki etkilerini değerlendirmeyi amaçlamaktadır.

Gereç ve Yöntem: McDonald ve Poser kriterlerine göre kesin MS tanısı almış UF veya anti-UF etkisi tarif eden 20 hasta çalışmaya dahil edildi. Soğutma işleminden önce optik nörit öyküsü olan tüm hastaların nörolojik, nöro-oftalmolojik muayeneleri ve elektrofizyolojik incelemeleri yapıldı. "Medivance Arctic Sun Temperature Management System" kullanılarak vücut sıcaklığ 1 yaklaşık $1{ }^{\circ} \mathrm{C}$ düşürüldü. Soğutma işlemi sonrasında tüm hastalar klinik ve elektrofizyolojik olarak tekrar değerlendirildi.

Address for Correspondence/Yazışma Adresi: Ahmet Onur Keskin MD, Baskent University Dr. Turgut Noyan Application and Research Center, Department of Neurology, Adana, Turkey

Phone: +90 5053870612 E-mail: aonurkeskin@gmail.com ORCID: orcid.org/0000-0002-2942-323X

Received/Geliș Tarihi: 28.12.2019 Accepted/Kabul Tarihi: 01.11.2020

${ }^{\circ}$ Copyright 2021 by Turkish Neurological Society

Turkish Journal of Neurology published by Galenos Publishing House. 


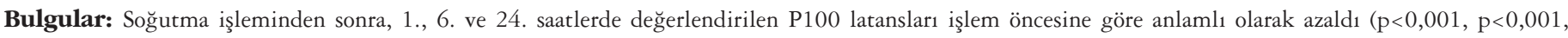

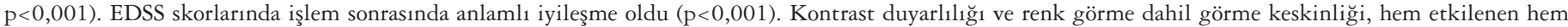
de etkilenmeyen gözlerde iyileşti $(\mathrm{p}<0,001)$.

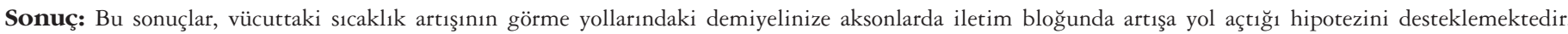

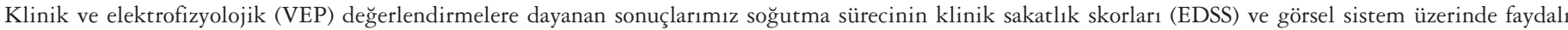

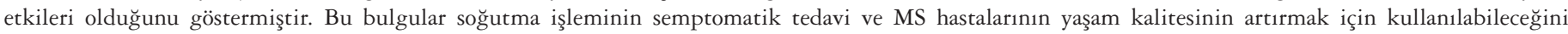
düşündürmektedir.

Anahtar Kelimeler: Multipl skleroz, görsel uyarılmış potansiyeller, soğutma etkisi, Uhthoff fenomeni

\section{Introduction}

Multiple sclerosis (MS) is the most common inflammatory demyelinating disease of the central nervous system (CNS) in young adults. MS is often associated with the involvement of the visual and oculomotor pathway, which can lead to clinically evident manifestations, such as optic neuritis, nystagmus, and diplopia (1). In some cases, the patient reports blurred vision even if visual acuity is normal. In other cases, no ocular symptoms are reported, but specific examinations can reveal subclinical abnormalities. Patients show a worsening of symptoms with an increase in body temperature. The temperature rise may be the result of exercise, a hot bath, or the prevailing climatic conditions. An estimated $60-80 \%$ of patients with MS experience a temporary worsening of clinical signs and neurologic symptoms with heat exposure. Heat sensitivity in MS is known as Uhthoff s phenomenon (UP) (2). This phenomenon most likely results from a slight elevation in core body temperature, which presumably causes increased neurologic dysfunction as a result of the development of conduction block in partially demyelinated axons $(3,4,5,6,7,8)$. Conversely, decreasing body temperature may alleviate the symptoms $(9,10,11,12,13,14)$. It is thought that the improvement observed clinically due to cooling is related to the temperature change in structures adjacent to demyelinated axons; however, this is not the only explanation $(11,12,13,14,15)$.

The aim of this study was to investigate the effects of cooling on both visual perception and visual evoked potential (VEP) after decreasing body temperature (approximately $-1{ }^{\circ} \mathrm{C}$ ) in patients with MS and determine whether the effects were sustained within 24 hours.

\section{Materials and Methods}

From January 2009 to July 2011, 20 patients (40 eyes) with MS [according to McDonald criteria (2005) and all with previous optic neuritis] were enrolled in the study. This study was conducted with the collaboration of the Departments of Neurology, Anesthesiology and Reanimation in Dokuz Eylul University Hospital in a multidisciplinary and cross-sectional manner. The study was guided by common ethical principles in research and according to the Declaration of Helsinki (16). The Regional Ethics Board of the Faculty of Medicine, Dokuz Eylul University, Turkey (July $6^{\text {th }}$, 2009/13501) approved the study. The procedure was explained in detail and informed consent was obtained from all patients. Thirteen of the patients were women and there were seven men. The mean age of the patients was 33.6 7.5 (range, 20-48) years. The disease duration was $4.25 \pm 3.16$ years. The mean number of relapses was $3.25 \pm 1.55$. Sixteen patients had relapsing-remitting MS, and four had secondary progressive MS. Four patients had a history of optic neuritis had bilateral (8 eyes), 16 unilateral (32 eyes), a total 40 affected eyes. The mean Expanded Disability Status Scale scores (EDSS) was 3.42 \pm 1.60 (Table 1). The disease was in remission in all patients. No patient was affected by any general disease apart from MS.

All patients underwent full ophthalmic and detailed neuroophtalmologic examinations, including best-corrected visual acuity measurements and fundus examinations. Visual field examinations were performed on each patient. Contrast sensitivity was evaluated in higher (100\%) and lower (2.5\% and $1.25 \%)$ contrast levels and the Sloan letter test (SLT) was used.

VEP pattern reversal was performed in the neurophysiology laboratory of our neurology department. VEP recordings were obtained pre-procedurally, and 1 hour, 6 hours, and 24 hours after the procedure, if improvement continued after 24 hours. P100 peak latency and amplitude were evaluated in both affected and unaffected eyes. P100 latency $>110$ ms [i.e., 2 standard deviation (SD) above the mean] was considered abnormal. P100 amplitude $<8.0 \pm 3.89$ was accepted abnormal.

Body cooling procedure: Body temperature was reduced by an average of $1{ }^{\circ} \mathrm{C}$ approximately over a 1-hour period using non-invasive, "latex-free", non-irritant hydrogel pads using the "Medivance Arctic Sun Temperature Management System" device.

Twelve hours before the procedure, patients started fasting as they do in pre-anesthesia/pre-sedation. The procedure was performed in a "Neurosensorial Neurophysiology Research Laboratory" suitably equipped with an oxygen tube, immobile aspirator, surgical stretcher, and technical equipment to stabilize the bag-mask-valve and vital functions for the implementation of anesthesia. The room temperature was kept stable at $21^{\circ} \mathrm{C}$ before the procedure. All patients underwent the procedure between 09:00 am and 12:00 pm.

\section{Table 1. Characteristics of samples}

\begin{tabular}{ll} 
Subjects $(\mathbf{n})$ & 20 \\
Sex $(\mathrm{F} / \mathrm{M}) \mathrm{n}$ & $13 / 7$ \\
Mean age (years) & $33.6 \pm 7.54$ \\
Duration of disease (years) & $4.25 \pm 3.16$ \\
Number of attacks & $3.25 \pm 1.55$ \\
RRMS n (\%) & $16(80.0)$ \\
SPMS n (\%) & $4(20.0)$ \\
ON number of attacks & $1.55 \pm 1.05$ \\
History of ON (U/B) n & $16 / 4$ \\
$\begin{array}{l}\text { Values are expressed as mean } \pm \text { standard deviation. F/M: Female/male, } \\
\text { ON: Optic neuritis, U/B: Unilateral/bilateral, RRMS: Relapsing-remitting mutiple } \\
\text { sclerosis, SPMS: Secondary progressive multiple sclerosis }\end{array}$ \\
\hline
\end{tabular}


Patients wore surgical gowns and colonoscopy shorts before the procedure. Four cooling pads were used. Two were placed over the thoracoabdominal region. The other two were placed over the femoral region. Later, a highly sensitive rectal probe with a feature of an accurate heat transducer (Mr. Smith Level $1{ }^{\circledR}$ Esophageal/ Rectal Temperature Probe with a 400 Series Thermistor) was inserted approximately $6-8 \mathrm{~cm}$ into the rectum. All the pads and the probe were secured and then connected to the device.

Before the procedure, baseline measurements of all patients [heart rate, systolic arterial blood pressure, diastolic arterial pressure, mean arterial pressure, oxygen saturation ( $\mathrm{SpO} 2)$, respiratory rate, rectal and oral body temperature] were recorded using a Hewlett Packard, M1094B-Saronno, Italy.

All the patients were administered a $0.9 \%$ saline infusion intravenously with a 20-gauge intravenous cannula inserted into the dorsum of the hand. Patients were delivered oxygen for 2-4 1/minute with a face mask during VEP. Titrated midazolam $(0.05 \mathrm{mg} / \mathrm{kg})$ and propofol $0.5 \mathrm{mg} / \mathrm{kg}$ were administered under the supervision of the anesthesia team. Sedation levels were assessed using the Ramsay Sedation Scale, and the sedation score was arranged as 3-4.

Sedation took approximately one hour. Rectal body temperature was continuously monitored using a "Medivance Arctic Sun Temperature Management System” device. Oral body temperature was checked every 10 minutes. The device had a feature that enabled reducing the temperature of the distilled water in the system down to $6{ }^{\circ} \mathrm{C}$. Based on the hypothermic response of the body, it cooled the water in the system at a rate to keep vital functions stable. After the rectal body temperature dropped approximately $1{ }^{\circ} \mathrm{C}$, the process was terminated.

\section{Statistical Analysis}

For the statistical analysis, the SPSS 15.0 for Windows software was used. Frequency tables are presented for the categorical variables, and descriptive statistics [average, $\mathrm{SD}$, median, minimum (min), maximum $(\max )]$ are presented for the numeric variables. In categorical comparison between the groups, cross-table statistics were performed and the significance level was examined using the chi-square test. To measure the dependence between the groups for which the normal distribution condition was not provided, Spearman's rho coefficient was calculated. The comparison of the values before and after the treatment was performed using the paired-sample t-test. The statistical alpha significance level was accepted as the condition where the $\mathrm{p}$ value was $<0.05$.

\section{Results}

In our study, 14/20 (70\%) patients with MS had the UP and all patients $(100 \%)$ were determined to have an improvement in their symptoms (anti-UP effect) with decreased ambient temperature. In $35 \%$ of patients, exercise/fatigue, and in $30 \%$, more than one factor could create UP and lead to worsening of clinical findings. In this study, 24 affected eyes and 16 unaffected eyes were evaluated. The mean time between the preceding $\mathrm{ON}$ attack and cooling procedure was $7.45 \pm 7.03$ months.

The mean time of the cooling procedure was $54.75 \pm 11.06$ minutes. EDSS scores, distance visual acuity, near visual acuity, color vision, and contrast sensitivity as evaluated using the SLT were improved significantly after the cooling procedure (Tables $2,3,4,5)$.

Table 2. Pre- and post-procedural changes in distance acuity. Near acuity and color vision in the unaffected eye

\begin{tabular}{|llll} 
& Pre & Post & P \\
Distance acuity & $0.83 \pm 0.19$ & $0.92 \pm 0.13$ & $0.002^{*}$ \\
Near acutiy & $1.35 \pm 0.58$ & $1.10 \pm 0.30$ & $0.025^{*}$ \\
Color vision & $2.05 \pm 2.83$ & $0.70 \pm 1.75$ & $0.005^{*}$ \\
*Values are expressed as mean \pm standard deviation & & \\
\hline
\end{tabular}

Table 3. Pre- and post-procedural changes of Sloan letter test scores

\begin{tabular}{|llll|} 
& Pre & Post & p \\
SLT 100\% & $55.40 \pm 5.13$ & $57.85 \pm 4.39$ & $<0.001$ \\
SLT 2.5\% & $29.50 \pm 7.31$ & $35.95 \pm 6.49$ & 0.001 \\
SLT $1.25 \%$ & $11.85 \pm 10.33$ & $21.85 \pm 10.30$ & $<0.001$ \\
SLT: Sloan letter test & & & \\
\hline
\end{tabular}

Table 4. Pre- and post-procedural changes in body temperature, $\mathrm{O}_{2}$ saturation, pulse, and blood pressure

\begin{tabular}{lll} 
& Pre & Post-difference \\
Rectal temperature $\left({ }^{\circ} \mathrm{C}\right)$ & $37.14 \pm 0.68$ & $-0.89 \pm 0.13$ \\
Oral temperature $\left({ }^{\circ} \mathrm{C}\right)$ & $36.76 \pm 0.55$ & $-1.31 \pm 0.26$ \\
Oxygen saturation $(\%)$ & $99.75 \pm 0.64$ & $-0.25 \pm 0.64$ \\
Pulse rate (per min) & $84.60 \pm 14.29$ & $-7.80 \pm 9.95$ \\
Systolic blood pressure (mmHg) & $111.25 \pm 10.87$ & $-9.50 \pm 6.86$ \\
Diastolic blood pressure (mmHg) & $70.75 \pm 10.04$ & $-8.75 \pm 7.76$ \\
\hline
\end{tabular}




\section{Cooling Procedure}

Prior to the cooling procedure, the rectal temperature was determined as an average $37.14 \pm 0.68^{\circ} \mathrm{C}$, and the oral temperature was determined as an average $36.75 \pm 0.54^{\circ} \mathrm{C}$. Once a $1{ }^{\circ} \mathrm{C}$ decrease in oral temperature was achieved, the procedure was terminated. The mean time of the cooling procedure was $54.75 \pm 11.06$ (range, 40-80 minutes). The rectal temperature after the procedure decreased by $0.89 \pm 0.13{ }^{\circ} \mathrm{C}$ on average, the oral temperature decreased by $1.3 \pm 0.26{ }^{\circ} \mathrm{C}$ on average. Before the procedure, the mean $\mathrm{SpO} 2$ was determined as $99.75 \pm 0.63 \%$, pulse $84.6 \pm 14.29 /$ $\mathrm{min}$, systolic blood pressure $111.25 \pm 10.86 \mathrm{mmHg}$, diastolic blood pressure $70.75 \pm 10.03 \mathrm{mmHg}$. After the procedure, the $\mathrm{SpO} 2$ decreased $0.25 \pm 0.64 \%$, pulse rate decreased $7.80 \pm 9.95$, systolic blood pressure decreased $9.50 \pm 6.86 \mathrm{mmHg}$, and diastolic blood pressure decreased $8.75 \pm 7.76 \mathrm{mmHg}$.

\section{VEP Results}

Pre-procedurally, VEP P100 latency distortion was delayed in all 24 eyes $(100 \%)$ that were affected by ON. VEP abnormality was determined in 8 out of 16 eyes $(50 \%)$ that were unaffected. Before cooling, the mean VEP P100 latency was $158.3 \pm 28.7$ msn in affected eyes and $125.9 \pm 16.1 \mathrm{msn}$ in unaffected eyes. The difference between affected and unaffected eyes was $32.4 \pm 30.4 \mathrm{msn}$ $(\mathrm{p}<0.001)$. In unaffected eyes, VEP latency was statically longer than the mean values of our laboratory data $(100.43 \pm 6.27 \mathrm{msec}$, max: 109 - min: $93 \mathrm{msec})(\mathrm{p}<0.05)$. After the cooling process, P100 latency significantly shortened at the $1^{\text {st }}(136.75 \pm 20.62$ $\mathrm{msn}), 6^{\text {th }}(140.53 \pm 21.34 \mathrm{msn})$ and $24^{\text {th }}(148.30 \pm 17.70 \mathrm{msn})$ hours in the affected eyes $(\mathrm{p}<0.05)$ (Figure 1$)$. The cooling procedure resulted in P100 latency shortening in the affected ( $\mathrm{n}=18$ eyes) and unaffected eyes ( $\mathrm{n}=8$ eyes) without affecting the amplitude (Figure 2). In 10 patients with MS, the cooling effect on VEP latency continued for 24 hours. Pre-procedurally, the mean P100 amplitude was $4.99 \pm 2.34$ microvolts in the affected eyes and $5.57 \pm 2.18$ microvolt in the unaffected eyes. P100 amplitude did not statistically change before and after the cooling procedure. However, P100 amplitudes were observed to increase in the affected eyes (in 9 patients after one hour, 12 patients after 6 hours, 7 patients after 24 hours). Moreover, it was found in the unaffected eyes that the P100 amplitudes had increased in 9 patients in the first hour, in 12 patients in the $6^{\text {th }}$ hour, and 4 patients in the $24^{\text {th }}$ hour after the procedure.

\section{Discussion}

Visual disturbances are common in MS and often a result of acute demyelinating optic neuropathy. Careful examination of patients with MS who have never had optic neuritis may also reveal asymptomatic visual loss. Demyelination commonly affects visual function, resulting in several neuro-ophthalmic symptoms and VEP changes. The changes of VEP latencies during pattern-

\section{Table 5. Pre- and post-procedural changes of EDSS score}

\begin{tabular}{llll|} 
& Pre & Post & p \\
EDSS score & $3.43 \pm 1.57$ & $2.71 \pm 1.49$ & $<0.001^{*}$ \\
Pyramidal EDSS score & $1.18 \pm 1.33$ & $1.01 \pm 1.19$ & $<0.042^{*}$ \\
Cerebellar EDSS score & $1.15 \pm 0.95$ & $0.71 \pm 0.85$ & $<0.004^{*}$ \\
Brainstem EDSS score & $1.22 \pm 0.86$ & $1.16 \pm 0.87$ & 0.33 \\
Sensory EDSS score & $1.92 \pm 0.65$ & $1.31 \pm 0.71$ & $<0.001^{*}$ \\
Visual EDSS score & $1.73 \pm 0.54$ & $0.67 \pm 0.63$ & $<0.001^{*}$ \\
"Values are expressed as median \pm standard deviation, EDSS: Expanded Disability Status Scale & \\
\hline
\end{tabular}

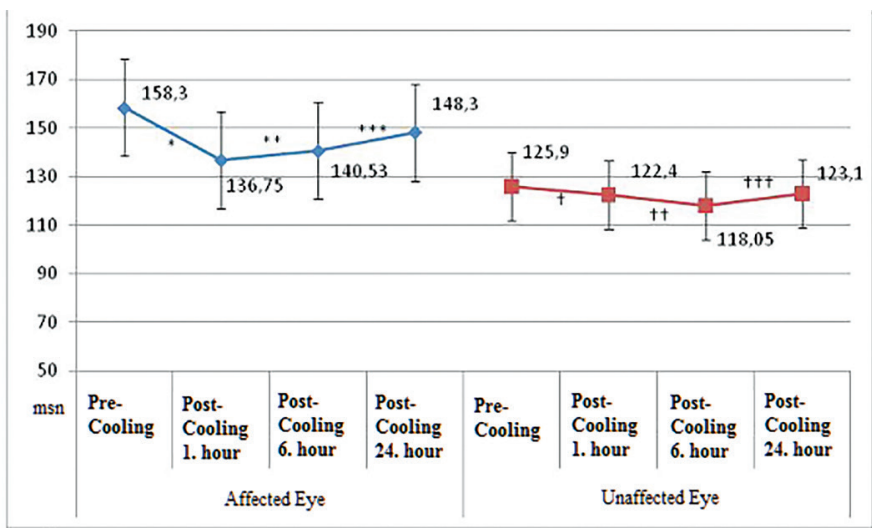

Figure 1. Cooling procedure and its effects on P100 latency VEP sample of a study subject with the left side on in pre- and post-cooling 1, 6 and 24 hours

${ }^{*} p<0.001,{ }^{\dagger} p=0.456, * * p<0.001,{ }^{\dagger \dagger} p=0.002, * * * p=0.011,{ }^{\dagger \dagger} p=0.269$, VEP: Visual evoked potential

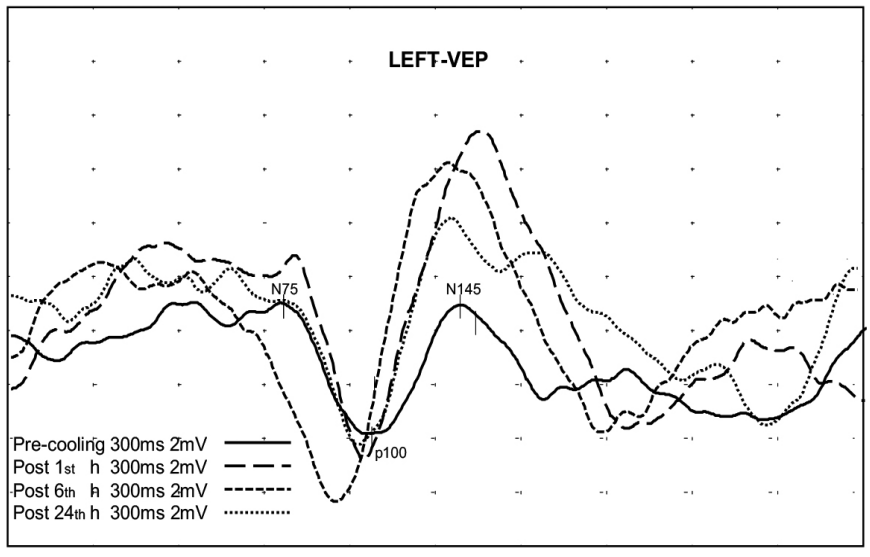

Figure 2. Cooling procedure and its effects on VEP. VEP sample of a study subject with the left side on in pre- and post-cooling 1, 6 and 24 hours

VEP: Visual evoked potential 
reversal stimulation are considered one of the most characteristic electrophysiologic signs in patients with MS. Such alterations are present almost invariably in subjects affected by optic neuritis $(17,18)$ and in a percentage that varies from $35 \%$ to $93 \%$, also in patients without symptoms and signs of visual system impairment (19).

MS is a progressive neurologic disorder that disrupts axonal myelin in the CNS. Demyelination produces alterations in saltatory conduction, decreased conduction velocity, and a predisposition to conduction block. Abnormal VEP can provide evidence for pathology to satisfy the diagnostic criteria of lesions disseminated in space in the absence of clinical findings and for relapse in a patient with new symptoms but no changes in clinical examination. The revised diagnostic criteria for MS include the provision for an abnormal VEP to serve as a diagnostic factor (20). Many patients with MS experience a severe exacerbation of their symptoms after a hot bath and this sensitivity to heat may be so extreme that even a hot drink will cause blurred vision.

The effect of heat on myelinated fibers is to increase conduction velocity up to a critical temperature when the conduction block develops abruptly (7). In demyelinated fibers, the increase in velocity is less and blocking occurs at a much lower temperature (21). The natural assumption is, therefore, that the temporary adverse effect of heat in patients with MS is caused by conduction block in demyelinated fibers and consequently the appearance of neurologic signs. An estimated $60-80 \%$ of patients with MS experience a temporary worsening of clinical signs and neurologic symptoms with heat exposure (10,22). Matthews et al. (4) studied the effects of raising body temperature on visual (VEP) and somatosensory evoked potentials (SEP) in normal subjects and patients with MS. The amplitude of the VEP was significantly reduced after heating in a normal subject and patients with MS but there was no effect on the latency of the potentials. Changes in amplitude could not be related to a reduction in acuity. In contrast, the cervical SEP was greatly disorganized after heating in many patients with MS, but the only effect in normal subjects was to reduce the latency by increasing peripheral conduction velocity. These results suggest that heat caused a conduction block in demyelinated axons in the sensory pathways of the cervical spinal cord. Bajada et al. (5) used the body bag method to examine the effects of induced hyperthermia on VEPs and saccade parameters in normal subjects and patients with MS and claimed that the body bag method for heating offered advantages for electrophysiologic studies over other methods $(23,24,25)$. They found that amplitude changes were more marked (reductions of up to $26 \%$ ) as was found by Matthews et al. (4). A higher temperature-induced reduction in nerve fiber action potential amplitude has been shown in the giant axon (26) and the possibility that an increase of temperature may alter the temporal pattern of impulse transmission or cause conduction block in some nerve fibers in the visual pathway has been considered (4). Bajada et al.'s (5) VEP findings in subjects with MS agreed with those of Matthews et al. (4), who also found a fall in P2 amplitude without significant latency changes after heating. Unlike Matthews et al. (4), who found a comparable reduction in P2 amplitude in their normal controls and patients with MS, Bajada et al. (5) found considerably greater amplitude reductions after heating in two patients with MS than in any of the control subjects. Reduced P2 amplitude and increased latency after heating may be due to changes in conduction in demyelinated nerve fibers in the visual pathway. It is known from experimental work in the peripheral nervous system that conduction in demyelinated fibers is extremely temperature-sensitive $(14,21)$.

Amplitude reduction without latency change would be more readily accounted for by reversible conduction block in demyelinated nerve fibers than by slowing of conduction, which would be more likely to cause a delayed response. Transient VEP amplitude reduction without latency change has also been shown to occur after exercise in some patients with MS (27). Phillips et al. (28) studied the effects of hyperthermia on evoked potentials in both healthy control and clinically definite MS under normothermic and hyperthermic $\left(+1{ }^{\circ} \mathrm{C}\right)$ conditions. Normal subjects showed no changes during hyperthermia, but patients with MS showed additional VEP abnormalities in hyperthermic conditions. In previous studies, the effects of hyperthermia on evoked responses were examined and decreased amplitude and increased latency after heating were found $(4,5,28,29)$. While cooling had no noticeable effect on EP delay in control subjects, a clear temporary reduction of EP delay after ingestion of ice was detected in five out of seven patients with MS. Heating had no noticeable effect on EP delay for the control subjects who were heated. Heating increased EP potential delay in some patients with MS but did not affect others. In contrast, cooling caused a clear change of P100 latency delay in patients with unilateral retrobulbar neuritis. Delays did not return to precooling values within one hour, but measurements continued for four hours after the end of cooling in one patient. In contrast, Regan et al. (29) observed a lack of correspondence between the effects of heating or cooling on visual perception and the latency of VEP obtained by the different methods in patients with MS. Although it is well known that heating worsens and cooling improves the signs and symptoms of MS, there are a few reports that signs and symptoms may worsen with exposure to cold $(30,31)$. The therapeutic effects of cooling in patients with MS investigated in previous studies were mentioned before $(4,5,28,29)$, but these studies had uncontrolled designs, unblinded evaluations, subjective outcome measures, and small size samples. Recently, the NASA/MS study group evaluated the acute and chronic effects of cooling on the motor and visual function in patients with MS. They reported that cooling therapy was objectively measurable but resulted in modest improvement in motor and visual function, as well as persistent subjective benefits (32). Cooling can probably reduce conduction block in demyelinated nerves, potentially improving symptoms of MS.

In our study, the cooling procedure resulted in P100 latency shortening both in the affected and unaffected eyes without significant amplitude changes in addition to the improvement of visual perception. The P100 changes due to the cooling procedure in our EP studies are generally different from the reported findings in the literature $(4,5,14,21,28)$. However, the results correlated with those of the NASA/MS Cooling Study Group (32). The P100 changes due to the cooling procedure defined in the literature are often amplitude changes, whereas we established that they are latency changes. On the other hand, one might suggest that P100 changes were caused by sedation. In our study, midazolam was also used for sedation. Koht et al. (33) studied three intravenous agents on SEP, one of which was midazolam. In their study, midazolam did not affect amplitude but increased latency, whereas in our study, VEP P100 amplitude did not change post procedurally but P100 
latency was shortened (33). Therefore, we suggest that sedation does not contribute to EP changes. Tanaka et al. (34) evaluated the effects of sevoflurane and propofol on an electroretinogram and VEPs and found that propofol did not significantly decrease the amplitude of VEPs at low doses (effect-site concentrations of 2 or $3 \mu \mathrm{g} / \mathrm{ml})$.

Brenneis et al. (35) suggested that the effects of temperature might be associated with multiple factors such as $\mathrm{pH}$, neurotransmitters, and electrolytes. Increased temperature may also influence the electrical properties of the nerve fiber by increasing the refractory period (partly mediated by potassium channel activation and sodium channel inactivation), which surpasses the action potential-generating processes (sodium channel activation) (36). In our opinion, temperature changes may cause ion channel changes like a fampridine effect. Cooling is reported to improve the symptoms of patients with MS, albeit transiently $(7,10)$. Improvement of symptoms and signs lasts as long as body temperature is maintained within the effective range. A reduction of body temperature of about $1{ }^{\circ} \mathrm{C}$ is necessary for such improvement (22).

\section{Conclusion}

In our study, the cooling effect continued for 24 hours in 10 patients with MS. We suggest that conduction in the visual pathway in demyelinating disease is affected by temperature decrease, as in the peripheral nervous system.

This study demonstrated that it is possible to induce transient and sustained improvement of neurologic deficits in patients with MS. The development of vest and head-vest cooling garments for the relief of symptoms is very important to increase the quality of life in MS.

Ethics

Ethics Committee Approval: The Regional Ethics Board of the Faculty of Medicine, Dokuz Eylul University, Turkey (July $6^{\text {th }}$, 2009/13501) approved the study.

Informed Consent: The procedure was explained in detail and informed consent was obtained from all patients.

Peer-review: Externally peer-reviewed.

\section{Authorship Contributions}

Surgical and Medical Practices: T.P., F.İ., L.İ.K., E.İ., Concept: T.P., A.O.K., F.İ., L.İ.K., E.İ., Design: T.P., A.O.K., F.İ., Data Collection or Processing: T.P., F.İ., L.İ.K.,, E.İ., Analysis or Interpretation: T.P., A.O.K., F.İ., E.İ., Literature Search: T.P., A.O.K., F.İ., E.İ., Writing: T.P., A.O.K., F.İ., E.İ.

Conflict of Interest: The authors have not declared any conflict of interest related to this article.

Financial Disclosure: No financial support was received from any institution or person for our study.

\section{References}

1. Balcer LJ. Multiple sclerosis and related demyelinating diseases. In: Miller NR, Neuman NJ, Biousse V, Kerrison JB, (eds.) Walsh and Hoyt's Clinical Neuroophthalmology. Baltimore: Lippincott Williams and Wilkins: 2005;60:3429- 3497.

2. Uhthoff W. Untersuchungen über die bei der Multiplen Herdsklerose vorkommenden Augenstörungen. Archiv Psychiatrie und Nervenkrankheiten. Berlin: August Hirschwald; 1889:303-410.
3. Davis FA. Axonal conduction studies based on some consideration of temperature effects in multiple sclerosis. Electroencephalogr Clin Neurophysiol 1970;28:281-286.

4. Matthews WB, Read DJ, Pountney E. Effect of raising body temperature on visual and somatosensory evoked potentials in patients with multiple sclerosis. J Neurol Neurosurg Psychiatry 1979;42:250-255.

5. Bajada S, Mastaglia FL, Black JL, Collins DW. Effects of induced hyperthermia on visual evoked potentials and saccade parameters in normal subjects and multiple sclerosis patients. J Neurol Neurosurg Psychiatry 1980;43:849-852.

6. Schauf CL, Davis FA. Impulse conduction in multiple sclerosis: A theoretical basis for modification by temperature and pharmacological agents. J Neurol Neurosurg Psychiatry 1974;37:152-161.

7. Beenaker EAC, Oparina TI, Telken A, et al. Cooling garment treatment in MS: Clinical improvement and decrease in leukocyte NO production. Neurology 2001;57:892-894.

8. Davis SL, Wilson TE, White AT, Frohman EM. Thermoregulation in multiple sclerosis. J Appl Physiol 2010;109:1531-1537.

9. Capello E, Gardella M, Leandri M, et al. Lowering body temperature with a cooling suit as symptomatic for thermosensitive multiple patients treatment sclerosis. ltal J Neurol Sci 1995;16:533-539.

10. Syndulko K, Jafari M, Woldanski A, Baumhefner RW, Tourtelotte WW. Effects of temperature in multiple sclerosis: A review of the literature. J Neurol Rehab 1996;10:23-34.

11. Ku YT, Montgomery LD, Wenzel KC, Webbon BW, Burks JS. Physiologic and thermal responses of male and female patients with multiple sclerosis to head and neck cooling. Am J Phys Med Rehabil 1999;78:447-456.

12. Ku YT, Montgomery LD, Lee HC, Luna B, Webbon BW. Physiologic and functional responses of MS patients to body cooling. Am J Phys Med Rehabil 2000;79:427-434.

13. Kinnmann J, Anderson U, Kinnan Y, Wetterqvist L. Temporary involvement of motor function in patients with multiple sclerosis after treatment with a cooling suit. J Neurol Rehab 1997;11:109-114.

14. Symington GR, Mackay IR, Currie TT. Improvement in multiple sclerosis during prolonged induced hypothermia. Neurology 1977;27:302-303.

15. Baker DG. Multiple sclerosis and thermoregulatory disfunction. J Appl Physiol 2002;92:1779-1780.

16. WMA Declaration of Helsinki-Ethical principles for medical research involving human subject. 59 WMA General assembly, Seoul, Korea, October 2008.

17. Halliday AM, McDonald WI, Mushin J. Delayed visual evoked response in optic neuritis. Lancet 1972;1:982-985.

18. Halliday AM. The visual evoked potentials in the investigation of diseases of the optic nerve. In: Halliday AM (eds.) Evoked Potentials in Clinical Testing. Edingburgh: Churchill Livingstone 1993;195-278.

19. Tarataglione A, Oneto A, Bandini F, et al. Electrophysiological detection of "silent" plaques in the optic pathways. Acta Neurol Scand 1987;76:246250.

20. Polman CH, Reingold SC, Edan G, et al. Diagnostic criteria for multiple sclerosis: 2005 revision to the "McDonald Criteria". Ann Neurol 2005;58:840-846.

21. Rasminsky M. The effects of temperature on conduction in demyelinated single nerve fibers. Arch Neurol 1972;28:287-292.

22. Watson W. Effects of lowering of body temperature on the symptoms and signs of multiple sclerosis. New Engl J Med 1959;261:1253-1259.

23. Romani A, BergamaschiR, Versino M, et al. Circadian and hypothermiainduced effects on visual and auditory evoked potentials in multiple sclerosis. Clin Neurophysiol 2000;111:1602-1606.

24. Jestico JV, Ellis PD. Changes in nystagmus on raising body temperature in clinically suspected and proved multiple sclerosis. Br Med J 1976;2:970972.

25. Namerow NS, Enns N. Visual evoked potentials in patients with multiple sclerosis. J Neurol Neurosurg Psychiatry 1972;35:829-833.

26. Chapman RA. Dependence on temperature of the conduction velocity of the action potential of the giant squid axon. Nature 1967;213:1143-1144.

27. Persson HE, Sachs C. Provoked visual impairment in multiple sclerosis studied by visual evoked responses. Electroencephalogr Clin Neurophysiol 1978;44:664-668. 
28. Phillips KR, Potvin AR, Syndulko K, et al. Multimodality evoked potentials and neurophysiological tests in multiple sclerosis. Effects of hyperthermia on test results. Arch Neurol 1983;40:159-164.

29. Regan D, Murray J, Silver R. Effect of body temperature on visual evoked potential delay and visual perception in multiple sclerosis. J Neurol Neurosurg Psychiatry 1977;40:1083-1091.

30. Simons DJ. A note on the effects of heat and cold upon certain symptoms of multiple sclerosis. Bull Neurol NY 1937;6:385-386.

31. Geller M. Appearance of signs and symptoms of multiple sclerosis in response to cold. Mt Sinai J Med 1974;41:127-130.

32. Schwid SR, Petrie MD, Murray R, et al. NASA/MS Cooling Study Group. A randomized study of the acute and chronic effects of cooling therapy for MS Neurology 2003;60:1955-1960.
33. Koht A, Schiitz W, Schmidt G, Schramm J, Watanabe E. Effects of etomidate, midazolam, and thiopental on median nervesomatosensory evoked potentials and the additive effects of fentanyl and nitrous oxide. Anesth Analg 1988,67:435-441.

34. Tanaka R, Tanaka S, Ichino T, et al. Differential effects of sevoflurane and propofol on an electroretinogram and visual evoked potentials. J Anesth 2020;34:298-302.

35. Brenneis M, Harrer G, Selzer H. [On the temperature sensitivity of multiple sclerosis patients (author's transl)]. Fortschr Neurol Psychiatr Grenzgeb 1979; $47: 320-325$.

36. Huxley AF. Ion movements during nerve activity. Ann NY Acad Sci 1959;81:221-246. 